\title{
Ecological strategies of Al-accumulating and non-accumulating functional groups from the cerrado sensu stricto
}

\author{
MARCELO C. DE SOUZA ${ }^{1,2}$, PAULA C.P. BUENO ${ }^{3}$, \\ LEONOR P.C. MORELLATO ${ }^{4}$ and GUSTAVO HABERMANN ${ }^{4}$ \\ ${ }^{1}$ Programa de Pós-Graduação em Ciências Biológicas (Biologia Vegetal), \\ Departamento de Botânica, Instituto de Biociências, Universidade Estadual \\ Paulista/UNESP, Avenida 24A, 1515, Bela Vista, 13506-900 Rio Claro, SP, Brasil \\ ${ }^{2}$ Departamento de Ciências Farmacêuticas, Faculdade de Ciências \\ Farmacêuticas de Ribeirão Preto, Universidade de São Paulo/USP, \\ Avenida do Café, s/n, Monte Alegre, 14040-903 Ribeirão Preto, SP, Brasil \\ ${ }^{3}$ Departamento de Química Orgânica, Instituto de Química, Universidade Estadual \\ Paulista/UNESP, Rua Prof. Francisco Degni, 55, Quintadinha, 14800-900 Araraquara, SP, Brasil \\ ${ }^{4}$ Departamento de Botânica, Instituto de Biociências, Universidade Estadual Paulista/UNESP, \\ Avenida 24A, 1515, Bela Vista, 13506-900 Rio Claro, SP, Brasil
}

Manuscript received on May 6, 2014; accepted for publication on October 24, 2014

\begin{abstract}
The cerrado's flora comprises aluminum-(Al) accumulating and non-accumulating plants, which coexist on acidic and Al-rich soils with low fertility. Despite their existence, the ecological importance or biological strategies of these functional groups have been little explored. We evaluated the leaf flushing patterns of both groups throughout a year; leaf concentrations of N, P, K, Ca, Mg, S, Al, total flavonoids and polyphenols; as well as the specific leaf area (SLA) on young and mature leaves within and between the groups. In Al-accumulating plants, leaf flushed throughout the year, mainly in May and September; for non-accumulating plants, leaf flushing peaked at the dry-wet seasons transition. However, these behaviors could not be associated with strategies for building up concentrations of defense compounds in leaves of any functional groups. Al-accumulating plants showed low leaf nutrient concentrations, while non-accumulating plants accumulated more macronutrients and produced leaves with high SLA since the juvenile leaf phase. This demonstrates that the increase in SLA is slower in Al-accumulating plants that are likely to achieve SLA values comparable to the rest of the plant community only in the wet season, when sunlight capture is important for the growth of new branches.
\end{abstract}

Key words: aluminum, community, herbivory, mineral nutrition, phenology, specific leaf area.

\section{INTRODUCTION}

Aluminum ( $\mathrm{Al})$ is the most abundant metal and the third most common element within the Earth's crust (von Uexküll and Mutert 1995). In the soil, soluble

Correspondence to: Marcelo Claro de Souza

E-mail:marcelo.claro.souza@gmail.com
$\mathrm{Al}\left(\mathrm{Al}^{3+}\right)$ is toxic to most crops, causing physical damage to cell walls (Horst et al. 2010) and root tips (Kopittke et al. 2008). Chelation and/or exclusion of $\mathrm{Al}$ at the root tip seem to be critical strategies for avoiding Al in crop plants (Ryan et al. 2011) and native species (Brunner and Sperisen 2013). 
However, some species from the cerrado vegetation accumulate large amounts of $\mathrm{Al}$, with no apparent damage to their metabolisms. These plants grow on the acidic and Al-rich soils from the cerrado and are known as Al-accumulating and non-accumulating species. They co-occur in the typical savanna-type vegetation, the cerrado sensu stricto (Haridasan 1982) and cerradão (dense cerrado) (Haridasan and Araújo 1988), and also in semi-deciduous forests (Araújo and Haridasan 1997, Haridasan and Araújo 2005) and gallery forests (Nascimento and Hay 1990).

Al-accumulating plants show 1000 to 15000 mg Al kg-1 LDM (leaf dry mass), whereas nonaccumulating plants store between 100 and 600 mg Al kg-1 LDM (Haridasan 1982, Jansen et al. 2002a). Despite the large number of woody species in the cerrado (1000 - 2000) (Ratter et al. 2003), only some species from few families have been identified as Al-accumulating plants in the cerrado sensu stricto: Miconia sp., Palicourea rigida, Qualea sp. and Vochysia sp. (Haridasan 1982). Notwithstanding, Al-accumulating plants are widely distributed among the distinct vegetation types. Haridasan (1982) observed 35\% of Alaccumulating species in a cerrado sensu stricto; Haridasan and Araújo (1988) found 18\% of these plants in a cerradão growing on a dystrophic soil, but less than $8 \%$ when this forest physiognomy was growing on a mesotrophic soil, and only $7 \%$ of Al-accumulating species were observed in a semideciduous forest (Araújo and Haridasan 1997, Haridasan and Araújo 2005).

Similar to climates found in African and Australian savannas, the cerrado's dry season occurs in the fall-winter, from May to October, and the warm and rainy season, between November and April (Ferreira Júnior et al. 2003, Camargo et al. 2011, Kissmann et al. 2012). Therefore, as in most tropical vegetation, leaves flush and develop during the spring-summer (Rossatto et al. 2009, Kushwaha et al. 2011, Camargo et al. 2013,
Alberton et al. 2014), as water availability and the warm weather enhance the photosynthetic rates and growth of new branches. However, we have found no comparative studies about leaf flushing in these two functional groups from the cerrado. Therefore, the first question we raise in this paper is whether these functional groups show distinct leaf phenology throughout a year.

Some cerrado woody plants flush at the end of the dry season (September), most probably because flushing just before the beginning of the wet season (October) avoids exposure of tender tissues during the peak of the wet season (January) (Rossatto et al. 2009, Alberton et al. 2014), when some herbivores, such as coleoptera (Marquis et al. 2002, Pinheiro et al. 2002), hemiptera, and isoptera (Pinheiro et al. 2002) cause significant leaf damage. Thus, the exposure of mature rather than young leaves in the wet season could avoid injuries (Mantovani and Martins 1988). Some species go further into herbivory protection and rapidly reach leaf maturity (Kursar and Coley 2003), investing in secondary metabolites including phenols, tannins, alkaloids, and flavonoids (Varanda et al. 2005). Therefore, the second question we raise is whether a possible distinct leaf phenology between both functional groups is associated with patterns of secondary metabolite production (flavonoids and polyphenols) in juvenile or mature leaves.

Finally, coriaceous leaves are characteristic of many cerrado plants. Arens (1958) hypothesized that edaphic Al causes sclerophyllous leaves in cerrado plants, which helps them survive seasonal droughts. However, coriaceous leaves are associated with low specific leaf area (SLA, $\mathrm{cm}^{2} \mathrm{~g}^{-1}$ ) and reduced nutritional status (Gonçalves-Alvim et al. 2006). Therefore, our third question is whether $\mathrm{Al}$ accumulation and nutritional status are associated with divergent SLA during leaf development in these two functional groups. Although both groups cooccur and grow on the same soils under the same 
climate, with restricted phylogenetic correlations [few Rubiaceae species are Al-accumulating or occur as non-accumulating species in the cerrado sensu stricto (Jansen et al. 2002a)], Al has not yet been demonstrated to be essential to these plants in this way. In this paper, we investigate possible ecological strategies for these groups that might be hidden behind leaf traits.

\section{MATERIALS AND METHODS}

\section{Study Site AND Species SELection}

This study was conducted in a cerrado sensu stricto fragment $\left(22^{\circ} 13^{\prime} \mathrm{S} 47^{\circ} 53^{\prime} \mathrm{W} ; 610 \mathrm{~m}\right.$ of altitude; 260 ha) at São José da Conquista farm, in central state of São Paulo, Brazil. This vegetation grows on an oxisol, which is sandy, acidic $(\mathrm{pH}<4.0)$, low in availability of macronutrients and high in exchangeable Al (Reys et al. 2013). The climate in this region is classified as Cwa (Köppen 1948) with wet summer and dry winter. The mean monthly temperature varies between $32^{\circ} \mathrm{C}$ in February and $18^{\circ} \mathrm{C}$ in July, and the total annual rainfall is of approximately $1520 \mathrm{~mm}$ (Camargo et al. 2011).

Using three plots of $15 \times 15 \mathrm{~m}$, we selected the most representative species among plots, considering only those with at least 4 individuals among plots. Searching for Al-accumulating species, as those described by Haridasan (1982, 2008), Medeiros and Haridasan (1985) and Haridasan and Araújo (1988, 2005), we grouped them into Al-accumulating and non-accumulating species. Only those species exhibiting more than $1000 \mathrm{mg} \mathrm{kg}^{-1}$ (mg Al kg${ }^{-1} \mathrm{LDM}$ ) were considered Al-accumulating species, while those showing less than $1000 \mathrm{mg} \mathrm{kg}^{-1}$ were regarded as nonaccumulating species. The Al-accumulating group was comprised of four species from two families (Melastomataceae and Vochysiaceae), and the nonaccumulating group consisted of 18 species from 13 families (Table I).

The small number of species in the Alaccumulating group is consistent with the few families from the cerrado to which Al-accumulating species belong, especially in the cerrado sensu stricto (Haridasan 1982, Medeiros and Haridasan 1985). In the present study, Al-accumulating plants comprised $22 \%$ of the species surveyed. This percentage is very close to the average proportion of Al-accumulating species (20\%) previously reported as occurring in a cerrado sensu stricto (Haridasan 1982) and cerradão (Haridasan and Araújo 1988). Similar to what has been previously observed in a cerrado sensu stricto (Haridasan 1982) and in a cerradão (Haridasan and Araújo 1988), we did not observe any congeneric species between the Alaccumulating and non-accumulating groups in the present study (Table I).

PHENOLOGICAL OBSERVATIONS

The evaluation of leaf flushing pattern of the two functional groups was carried out monthly from 2005 to 2011 by the Phenology Laboratory at Unesp, Rio Claro, Brazil. These evaluations were performed on 36 transects, measuring $25 \mathrm{x}$ $2 \mathrm{~m}$ and $50 \mathrm{~m}$ distant from each other, that were established on the southern and eastern faces of the experimental fragment (Camargo et al. 2013, Alberton et al. 2014). The presence or absence of leaf flushing was registered according to Morellato et al. (2000, 2010). A total of 804 individuals, being 227 Al-accumulating and 577 non-accumulating plants, were identified in the transects.

\section{LEAF TRAITS}

Mature leaves were sampled in the second week of February (wet season) and young leaves, in the first week of September 2011 (at the peak of the dry season). The canopy of each plant was divided into cardinal directions and leaves were collected from 4-6 plants per species, according to the availability of leaves in each season. Leaf subsamples from each cardinal direction on each plant (replications) were mixed, taken to the laboratory, and washed under deionized water. 
TABLE I

List of Al-accumulating and non-accumulating species in a cerrado sensu stricto, southeastern Brazil.

\begin{tabular}{|c|c|c|}
\hline Family & Species & Leaf deciduousness \\
\hline \multicolumn{3}{|c|}{ Al-non-accumulating } \\
\hline Annonaceae & Annona coriacea Mart. & EG \\
\hline Annonaceae & Xylopia aromatica (Lam.) Mart. & EG \\
\hline Apocynaceae & Aspidosperma tomentosum Mart. & $\mathrm{D}$ \\
\hline Caryocaraceae & Caryocar brasiliensis A.St.-Hil. & $\mathrm{D}$ \\
\hline Erythroxylaceae & Erythroxylum suberosum A.St.-Hil. & $\mathrm{BD}$ \\
\hline Erythroxylaceae & Erythroxylum tortuosum Mart. & $\mathrm{BD}$ \\
\hline Erythroxylaceae & Erythroxylum pelleterianum A.St.-Hil. & $\mathrm{D}$ \\
\hline Malpighiaceae & Byrsonima basiloba A.Juss. & EG \\
\hline Malpighiaceae & Byrsonima intermedia A.Juss. & EG \\
\hline Malpighiaceae & Banisteriopsis variabilis B.Gates & $\mathrm{D}$ \\
\hline Malvaceae & Eriotheca gracilipes (K.Schum.) A.Robyns & $\mathrm{D}$ \\
\hline Myrsinaceae & Rapanea umbellata Mart. & EG \\
\hline Myrtaceae & Myrcia bella Cambess. & $\mathrm{BD}$ \\
\hline Nyctaginaceae & Guapira opposita (Vell.) Reitz & $\mathrm{BD}$ \\
\hline Rubiaceae & Tocoyena formosa (Cham. \& Schltdl.) K.Schum. & $\mathrm{D}$ \\
\hline Salicaceae & Casearia sylvestris Swartz & $\mathrm{BD}$ \\
\hline Sapotaceae & Pouteria torta (Mart.) Radlk. & EG \\
\hline \multicolumn{3}{|c|}{ Al-accumulating } \\
\hline Melastomataceae & Miconia albicans (Sw.) Triana & EG \\
\hline Melastomataceae & Miconia rubiginosa (Bonpl.) A.DC. & EG \\
\hline Melastomataceae & Miconia fallax DC. & EG \\
\hline Vochysiaceae & Qualea grandiflora Mart. & $\mathrm{BD}$ \\
\hline
\end{tabular}

EG - evergreen, BD - brevideciduous, D - deciduous.

Five leaf discs of a known area $\left(\mathrm{cm}^{2}\right)$ were excised from each of the six leaves that were sampled per plant. The leaf discs were oven-dried to constant dry mass at $60^{\circ} \mathrm{C}$, and SLA was calculated as the ratio between leaf area $\left(\mathrm{cm}^{2}\right)$ and leaf dry mass (g) (Habermann and Bressan 2011).

For determining the nutritional status, leaves were oven-dried at $60^{\circ} \mathrm{C}$ (to avoid $\mathrm{N}$ volatilization) to constant dry mass, ground and digested in a nitric-percloric acids solution. Leaf concentrations of $\mathrm{Ca}$ and $\mathrm{Mg}$ were determined by the atomic absorption spectrophotometer method; $\mathrm{K}$ was determined in a flame photometer; $\mathrm{S}$ was determined using a turbidimetric method; $\mathrm{P}$ and Al were quantified colorimetrically, and $\mathrm{N}$ was measured by the micro-Kjeldahl method (Sarruge and Haag 1974, Dantas and Batalha 2011).

\section{SECONDARY METABOLITES}

The total polyphenol concentration was expressed as $\mathrm{mg} \mathrm{g}^{-1}$ LDM (Cortés-Rojas et al. 2012), which employed adaptations of the FolinDenis colorimetric method. Leaves were dried at $50^{\circ} \mathrm{C}$ for $96 \mathrm{~h}$, ground to pass through a 20 mesh sieve (particles size $\sim 840 \mu \mathrm{m}$ ), and 50 $\mathrm{mg}$ were extracted in a $2.5 \mathrm{~mL}$ methanol:water (7:3) solution, after $1 \mathrm{~h}$ in ultrasound bath. The crude extract was diluted 10 times, and $155 \mu \mathrm{L}$ of distilled water, $20 \mu \mathrm{L}$ of Folin-Denis reagent, $20 \mu \mathrm{L}$ of $\mathrm{Na}_{2} \mathrm{CO}_{3}$ saturated at $35 \%$, and $5 \mu \mathrm{L}$ of the crude extract were deposited into each well of a 96-well microtiter plate. Absorbance values were measured at $760 \mathrm{~nm}$ using a microtiter plate reader, after $30 \mathrm{~min}$ of incubation in the dark at room temperature. 
The total flavonoid concentration, calculated as quercetin from a calibration curve and also expressed as $\mathrm{mg} \mathrm{LDM}^{-1}(\mathrm{~g})$, was measured using adaptations (Woisky and Salatino 1998) of a protocol that also employed 96-well microtiter plates. We poured $175 \mu \mathrm{L}$ of methanol, $5 \mu \mathrm{L}$ of $\mathrm{AlCl}_{3}$ at $35 \%$, and $20 \mu \mathrm{L}$ of the crude extract into each well, and absorbance values were measured at $425 \mathrm{~nm}$ using a microtiter plate reader, after $30 \mathrm{~min}$ of incubation in the dark, at room temperature.

\section{StATISTICAL ANALYSES}

We applied circular statistics to test for the occurrence of seasonality on leaf flushing of both functional groups (Morellato et al. 2000, 2010). The pattern of leaf flushing was described based on an activity index, which indicates the percentage of individuals manifesting a certain phenophase on each observation date (Camargo et al. 2013). To test data for the uniformity of average leaf flushing throughout the year or in a specific period of the year, we applied the Rayleigh test (Zar 1999).

A multivariate ANOVA at 5\% level was used to compare leaf traits (concentrations of $\mathrm{N}, \mathrm{P}, \mathrm{K}$, $\mathrm{Ca}, \mathrm{Mg}, \mathrm{S}, \mathrm{Al}$, flavonoids, total polyphenols and SLA) between young and mature leaves in the Alaccumulating and non-accumulating plants, and between these functional groups. To obtain normality, data were Box-cox transformed $\left(\mathrm{x}^{(1-(4 / 2))}\right)$ (Box and Cox 1964). We used four replications (plants) per species wich resulted in $16 \mathrm{Al}$-accumulating and 72 non-accumulating plants being assessed.

The relative percentage change $\left(\mathrm{RPC}=\left(\left(\mathrm{C}_{\mathrm{y}}-\mathrm{C}_{\mathrm{m}}\right) /\right.\right.$ $\left.\mathrm{C}_{\mathrm{y}}\right) 100 \%$ ) in leaf nutrients ( $, \mathrm{P}, \mathrm{K}, \mathrm{Ca}, \mathrm{Mg}, \mathrm{S}$, and $\mathrm{Al}$ ) from young to mature leaves of both groups of plants was calculated according to Teklay (2004), in such a manner that $\mathrm{C}_{\mathrm{y}}$ denoted the concentration of a target leaf nutrient in young leaves, and $\mathrm{C}_{\mathrm{m}}$ denoted the concentration of a target leaf nutrient in mature leaves. Positive RPC values indicate resorption, whereas negative values suggest enrichment of nutrients from the juvenile to the mature leaf phase.
We performed a multivariate ANOVA at 5\% level to test for differences in RPC between the functional groups. For N, P, K, Ca and $\mathrm{Mg}, \mathrm{RPC}$ is expressed in $\mathrm{g} \mathrm{cm}^{-2}$; for $\mathrm{Al}$, this value is expressed in $\mathrm{mg} \mathrm{cm}^{-2}$.

\section{RESULTS}

Both Al-accumulating and non-accumulating species flushed throughout the year (Fig. 1A-B). Non-accumulating species exhibited seasonal leaf flushing $(\mathrm{p}<0.001, \mathrm{Z}=0.52, \mathrm{r}=0.50)$ with a peak activity in September (mean angle $=246^{\circ}$ ), while Al-accumulating plants showed a bimodal flushing pattern, with high flushing intensity in May and September (Fig. 1A-B). According to Morellato et al. (2010), the Rayleigh test is not applicable (and its usage would be incorrect) when a bimodal phenological pattern is evident. Therefore, this test was not used for evaluating phenological results of the Al-accumulating plants.

Leaves of non-accumulating plants showed higher macronutrient (except for S) concentrations in relation to the Al-accumulating plants, and while non-accumulating plants diminished their nutrient concentrations from the juvenile to the mature leaf phase (except for $\mathrm{Ca}$ and $\mathrm{Mg}$ ), Al-accumulating species maintained these concentrations (except for $\mathrm{Mg}$ ) between leaf phases (Table II). Al concentration conspicuously increased from the juvenile to the mature leaf phase of Al-accumulating plants, whereas it remained unchanged between leaf phases in non-accumulating plants (Table II).

Leaves of non-accumulating plants showed the same SLA between leaf phases, whereas SLA values of Al-accumulating plants increased from the juvenile to the mature leaf phase, when values became similar to those of non-accumulating plants (Table II).

In non-accumulating plants, total leaf flavonoids concentration was higher than in Alaccumulating plants, and while non-accumulating plants decreased total leaf flavonoids concentration from the juvenile to the mature leaf phase, this compound had similar concentrations between leaf 

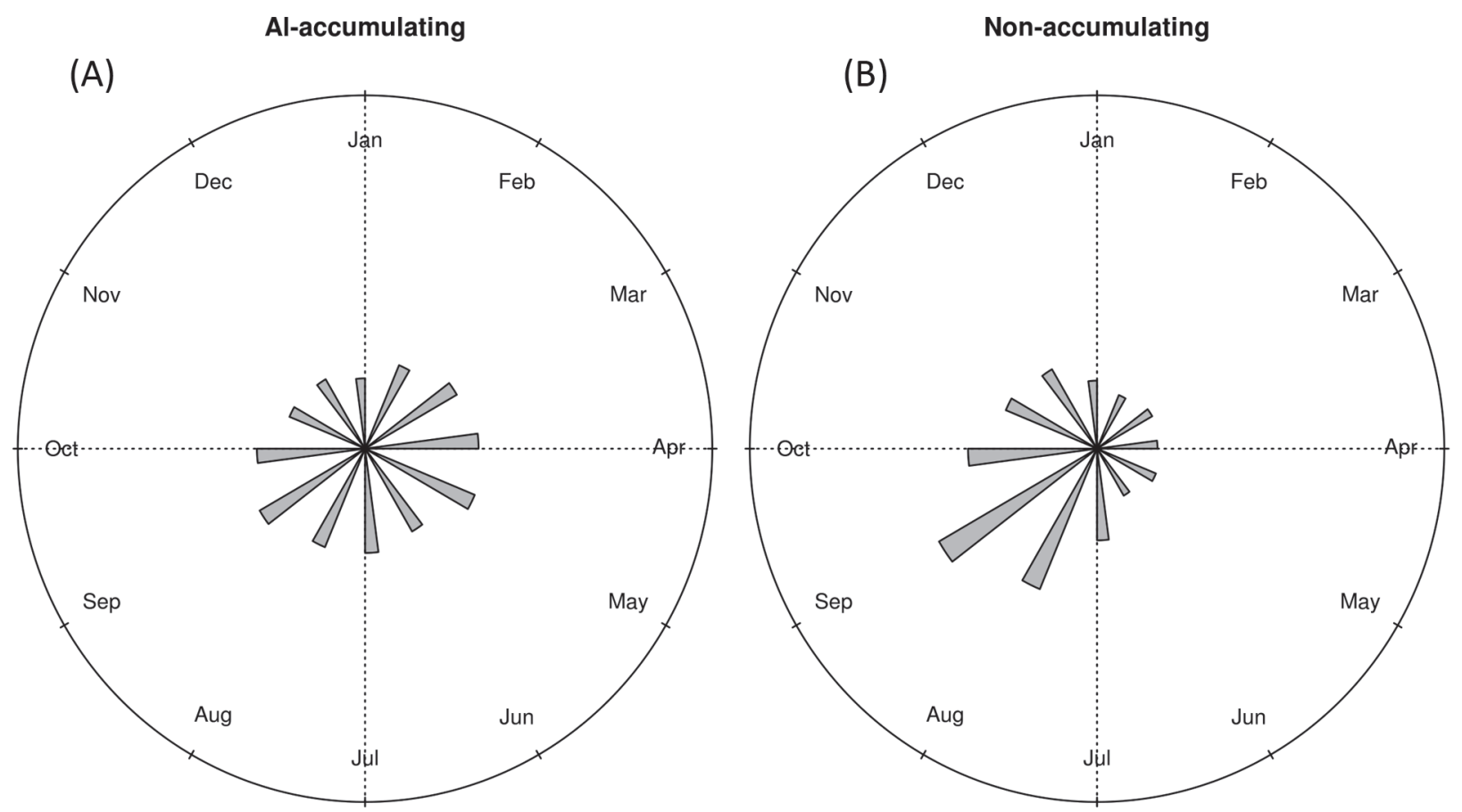

Fig. 1 - Average annual leaf-flushing distribution in (A) Al-accumulating and (B) non-accumulating plants between 2005 and 2011, in a cerrado sensu stricto, southeastern Brazil.

phases in Al-accumulating plants. Total polyphenols concentration, on the contrary, was higher in Alaccumulating in relation to non-accumulating plants, and for both groups this compound showed similar concentrations between leaf phases (Table II).

As expected, Al-accumulating plants exhibited $\mathrm{Al}$ enrichment of more than $100 \%$ from the juvenile to the mature leaf phase, whereas non-accumulating plants showed $\mathrm{Al}$ resorption of $14 \%$ between leaf phases. In addition, Al-accumulating plants showed a seven-fold higher $\mathrm{N}$ resorption when compared to the non-accumulating plants (Table III).

\section{DISCUSSION}

For cerrado species, leaf flushing generally occurs at the transition from the dry to the wet season (Rossatto et al. 2009, Alberton et al. 2014). However, non-accumulating plants flushed at the end of the dry season (September), while Al-accumulating plants flushed throughout the year, but more intensely at the end of both the dry (September) and the wet (April/May) season. In addition, in the present study, $\mathrm{Al}$-accumulating plants were composed of evergreen and semi-deciduous species, and non-accumulating plants consisted of evergreen, deciduous and semideciduous species. This shows that despite the diverse phenological behavior of cerrado species, Alaccumulating and non-accumulating species flush differently (Fig. 1A-B), and future studies should address specific issues regarding the leaf ecological strategies for both functional groups.

For tropical plants, young leaves generally suffer higher rates of herbivory, requiring greater diversity of secondary metabolites (Kursar et al. 1999) in comparison to mature leaves (Coley and Barone 1996). In the cerrado, insects seem to prefer young leaves whereas pathogens more often attack mature leaves (Marquis et al. 2001). For instance, Varanda et al. (2008) demonstrated caterpillars' preference for young expanding leaves of Xylopia 
TABLE II

Mean values ( \pm sd) of leaf concentrations of $\mathrm{N}, \mathrm{P}, \mathrm{K}, \mathrm{Ca}, \mathrm{Mg}, \mathrm{S}, \mathrm{Al}$, flavonoids, total polyphenols and specific leaf area (SLA) in young (Y) and mature (M) leaves of Alaccumulating and non-accumulating plants in a cerrado sensu stricto, southeastern Brazil.

\begin{tabular}{cccccc}
\hline Traits & Phenophase & \multicolumn{2}{c}{ Al-non-accumulating } & \multicolumn{3}{c}{ Al-accumulating } \\
\hline $\mathrm{N}\left(\mathrm{g} \mathrm{kg}^{-1}\right)$ & $\mathrm{Y}$ & $24.76 \pm 11.07$ & $\mathrm{aA}$ & $16.45 \pm 4.52$ & $\mathrm{aB}$ \\
& $\mathrm{M}$ & $19.03 \pm 8.41$ & $\mathrm{bA}$ & $13.33 \pm 1.52$ & $\mathrm{aB}$ \\
$\mathrm{P}\left(\mathrm{g} \mathrm{kg}^{-1}\right)$ & $\mathrm{Y}$ & $2.04 \pm 1.43$ & $\mathrm{aA}$ & $0.78 \pm 0.30$ & $\mathrm{aB}$ \\
& $\mathrm{M}$ & $1.12 \pm 0.34$ & $\mathrm{bA}$ & $0.73 \pm 0.09$ & $\mathrm{aB}$ \\
$\mathrm{K}\left(\mathrm{g} \mathrm{kg}^{-1}\right)$ & $\mathrm{Y}$ & $8.39 \pm 5.85$ & $\mathrm{aA}$ & $2.64 \pm 1.22$ & $\mathrm{aB}$ \\
& $\mathrm{M}$ & $4.19 \pm 1.73$ & $\mathrm{bA}$ & $2.19 \pm 0.44$ & $\mathrm{aB}$ \\
$\mathrm{Ca}\left(\mathrm{g} \mathrm{kg}^{-1}\right)$ & $\mathrm{Y}$ & $5.75 \pm 3.29$ & $\mathrm{aA}$ & $3.11 \pm 0.88$ & $\mathrm{aB}$ \\
& $\mathrm{M}$ & $5.62 \pm 1.97$ & $\mathrm{aA}$ & $3.58 \pm 0.71$ & $\mathrm{aB}$ \\
$\mathrm{Mg}\left(\mathrm{g} \mathrm{kg}^{-1}\right)$ & $\mathrm{Y}$ & $2.23 \pm 0.77$ & $\mathrm{aA}$ & $1.57 \pm 0.42$ & $\mathrm{aB}$ \\
& $\mathrm{M}$ & $2.09 \pm 0.70$ & $\mathrm{aA}$ & $1.22 \pm 0.20$ & $\mathrm{bB}$ \\
$\mathrm{S}\left(\mathrm{g} \mathrm{kg}^{-1}\right)$ & $\mathrm{Y}$ & $1.09 \pm 0.56$ & $\mathrm{aA}$ & $0.82 \pm 0.18$ & $\mathrm{aA}$ \\
& $\mathrm{M}$ & $0.83 \pm 0.34$ & $\mathrm{bA}$ & $0.92 \pm 0.31$ & $\mathrm{aA}$ \\
$\mathrm{Al}\left(\mathrm{mg} \mathrm{kg}^{-1}\right)$ & $\mathrm{Y}$ & $200.06 \pm 138.49$ & $\mathrm{aB}$ & $1546.60 \pm 139.49$ & $\mathrm{bA}$ \\
& $\mathrm{M}$ & $181.88 \pm 140.77$ & $\mathrm{aB}$ & $4867.36 \pm 1782.85$ & $\mathrm{aA}$ \\
$\mathrm{SLA}\left(\mathrm{cm}^{2} \mathrm{~g}^{-1}\right)$ & $\mathrm{Y}$ & $132.98 \pm 50.23$ & $\mathrm{aA}$ & $88.11 \pm 13.85$ & $\mathrm{bB}$ \\
& $\mathrm{M}$ & $122.23 \pm 32.03$ & $\mathrm{aA}$ & $145.54 \pm 62.01$ & $\mathrm{aA}$ \\
Flavonoids $\left(\mathrm{mg} \mathrm{g}^{-1}\right)$ & $\mathrm{Y}$ & $5.11 \pm 2.41$ & $\mathrm{aA}$ & $2.10 \pm 0.41$ & $\mathrm{aB}$ \\
& $\mathrm{M}$ & $3.66 \pm 2.81$ & $\mathrm{bA}$ & $1.79 \pm 0.23$ & $\mathrm{aB}$ \\
Polyphenols $\left(\mathrm{mg} \mathrm{g}^{-1}\right)$ & $\mathrm{Y}$ & $6.48 \pm 1.88$ & $\mathrm{aB}$ & $7.53 \pm 0.08$ & $\mathrm{aA}$ \\
& $\mathrm{M}$ & $6.02 \pm 1.95$ & $\mathrm{aB}$ & $7.81 \pm 0.53$ & $\mathrm{aA}$ \\
\hline
\end{tabular}

Different lower case letters indicate significant differences between young (Y) and mature (M) leaves in each functional group. Different upper case letters indicate significant differences between Al- accumulating and non-accumulating functional groups.

TABLE III

Mean Relative Percentage Change $( \pm$ sd) in the concentration of $\mathrm{N}, \mathrm{P}, \mathrm{K}, \mathrm{Ca}, \mathrm{Mg}, \mathrm{S}$ and $\mathrm{Al}$ in $\mathrm{Al}-$ accumulating and non-accumulating species in a cerrado sensu stricto, southeastern Brazil. Positive values show resorption whereas negative values show enrichment of nutrients from the juvenile to the mature leaf phase. $\mathrm{N}, \mathrm{P}, \mathrm{K}, \mathrm{Ca}, \mathrm{Mg}$ and $\mathrm{S}$ are expressed in $\mathrm{g} \mathrm{cm}^{-2}$ and $\mathrm{Al}$ is expressed in $\mathrm{mg} \mathrm{cm}^{-2}$.

\begin{tabular}{cccc}
\hline Traits & Al-non-accumulating & Al-accumulating & $\mathbf{p}$ \\
\hline $\mathrm{N}$ & $6.86 \pm 51.91$ & $43.45 \pm 16.78$ & $<0.02$ \\
$\mathrm{P}$ & $20.78 \pm 43.28$ & $33.39 \pm 19.14$ & $\mathrm{~ns}$ \\
$\mathrm{~K}$ & $23.30 \pm 53.58$ & $32.40 \pm 33.95$ & $\mathrm{~ns}$ \\
$\mathrm{Ca}$ & $-87.44 \pm 245.57$ & $7.39 \pm 56.62$ & $\mathrm{~ns}$ \\
$\mathrm{Mg}$ & $-19.45 \pm 101.05$ & $42.93 \pm 28.35$ & $<0.04$ \\
$\mathrm{~S}$ & $7.49 \pm 43.25$ & $20.80 \pm 31.14$ & $\mathrm{~ns}$ \\
$\mathrm{Al}$ & $14.24 \pm 54.18$ & $-101.18 \pm 72.27$ & $<0.001$ \\
\hline
\end{tabular}

aromatica, a non-accumulating species from the cerrado, as compared to their tannin-enriched mature leaves. Thus, secondary metabolites have frequently been associated with leaf protection against herbivores and pathogens.

The escape strategy (flushing at the drywet seasons interface) has been extensively debated (Silva and Batalha 2011) with no clear understanding for cerrado plants. Except for some insect orders (Marquis et al. 2002, Pinheiro et al. 2002), herbivory pressure in the cerrado is apparently similar throughout the year (Marquis et al. 2002). Insect leaf damage also seems to be independent of leaf age (Gonçalves-Alvim et al. 2011) and the season of escape may also depend on herbivore species (Marquis et al. 2001), although Silva and Batalha (2011) argue that herbivory is underestimated in the cerrado.

For both groups of plants studied here, the secondary metabolism seems to be under balance. The total leaf polyphenols, which include tannins, 
are higher in Al-accumulating in relation to nonaccumulating plants, whereas the opposite is observed for leaf flavonoids. Furthermore, no conspicuous differences in these metabolites appear between leaf phases in any of the plant groups, weakening any suggestion of escape strategy involving these compounds during leaf development. Indeed, although high leaf Al concentration has been demonstrated to be associated with low leaf tannin concentration in Qualea parviflora, an Alaccumulating species from the cerrado, leaf tannin concentration does not influence the herbivory leaf damage in this species (Gonçalves-Alvim et al. 2011). In addition, colonies of Atta sexdens (Hymenoptera: Formicidae) significantly declined when the ants were fed with mature leaves of $Q$. parviflora due to the $\mathrm{Al}$ accumulation in the ants' body (Rébula et al. 2008). Nascimento et al. (1990) and Nascimento (1987) also observed lower herbivory rates in two Al-accumulating species (Vochysia rufa and $V$. divergens) in relation to Curatella americana, a non-accumulating species from the cerrado. These authors ascribed ant's death and the low herbivory rate to $\mathrm{Al}$ toxicity, contrasting with the theory proposed by Arens (1958), who suggested that Al accumulation in leaves of cerrado plants help them survive seasonal droughts. Therefore, our results also show that $\mathrm{Al}$ accumulation is not associated with strategies for building up concentrations of defense compounds in leaves, thus weakening any suggestion of involvement of secondary metabolites in herbivory escape strategies for any of these functional groups.

Non-accumulating plants store more macronutrients (except for $\mathrm{S}$ ) than Al-accumulating plants, and produce leaves with high SLA since the juvenile leaf phase. Therefore, in relation to the Alaccumulating plants, the non-accumulating plants emit new leaves at the end of the dry season which rapidly optimize light capture for photosynthesis. Species possessing high SLA, such as forest species (Hoffmann et al. 2005, Habermann and Bressan 2011, Rossatto et al. 2013) and deciduous savanna species (Franco et al. 2005) show high leaf nutrient contents, such as $\mathrm{N}$ and $\mathrm{P}$ that are closely related to photosynthetic activities (Reich et al. 2009). This strategy, which is performed by the nonaccumulating plants, implies low leaf construction costs (Franco et al. 2005).

$\mathrm{Al}$-accumulating plants store less macronutrient than non-accumulating plants and gradually increase SLA from the juvenile to the mature leaf phase. In contrast to non-accumulating plants, the astonishing Al enrichment from the juvenile to the mature leaf phase in Al-accumulating plants could be associated with competition against macronutrients for allocation in the mesophyll of these plants, as described for many native species (Brunner and Sperisen 2013). Competition among nutrients can be detected only by studies of nutrient absorption dynamics, which are difficult to perform in the field. However, although N, P, K, Ca and S concentrations were lower in the leaves of $\mathrm{Al}$-accumulating plants, these values remained unchanged between leaf phases, indicating absence of competition between $\mathrm{Al}$ and macronutrients in these plants.

Thus, the lack of metabolic resources (macronutrients, especially $\mathrm{N}$ and $\mathrm{P}$ ) in $\mathrm{Al}$-accumulating plants does not seem to support a high SLA since the juvenile leaf phase. This group of plants flushes throughout the year and gradually increases SLA from the juvenile to the mature leaf phase, and are likely to match SLA values of the rest of the plant community only in the wet season, when possessing high SLA is important for light capture and photosynthesis. This strategy seems to be analogous to that exhibited by evergreen savanna species (Franco et al. 2005, Hoffmann et al. 2005, Habermann and Bressan 2011), which have high leaf construction costs involved in the development of non-photosynthetic tissues, such as fibers and cell walls rather than chloroplasts. In fact, the sclerophyllous leaf morphology in $Q$. parviflora is associated with low supply rates of macronutrient to their mesophyll (Gonçalves-Alvim et al. 2006). 
One may still argue that there is no phylogenetic context between the two groups of plants studied here, since the $\mathrm{Al}$ accumulation trait is restricted to three families occurring in the cerrado sensu stricto: Melastomataceae (Myconia sp.), Rubiacea (Palicourea rigida) and Vochysiacea (Qualea sp., Vochysia sp., Salvertia convallariodora) (Haridasan 1982, 1987, 2008, Jansen et al. 2002a, b, 2003, 2004). However, when studying herbivory defense traits among 61 species from 29 families in a cerrado plant community, Silva and Batalha (2011) found that phylogeny does not determine the suit of antiherbivory traits among the species. As mentioned above, Al accumulation is highly conserved in only $15-22 \%$ cerrado woody species (Haridasan 1982, Haridasan and Araújo 1988). Considering that both groups of plants grow on the same Al-rich soils and under the same climate, it is intriguing why the other $78-85 \%$ species have not conserved this trait. Al-accumulating species might have survived some environmental filters that act over cerrado species, while non-accumulating ancestors have not, since the cerrado imposes many filters on species, guilds and functional groups (Silva and Batalha 2006).

In conclusion, flushing at the dry-wet season transition for non-accumulating plants, and throughout the year for Al-accumulating plants can not be associated with strategies for building up concentrations of defense compounds in leaves of either of the groups. In addition, non-accumulating plants accumulate more macronutrients and produce leaves with high SLA as of the juvenile leaf phase, while leaves of Alaccumulating plants show a low level of nutrient status. This demonstrates that the increase in SLA is slower in Al-accumulating plants that are likely to achieve SLA values comparable to the rest of the plant community only in the wet season, when sunlight capture is important for the growth of new branches.

\section{ACKNOWLEDGMENTS}

MCS acknowledges the Coordenação de Aperfeiçoamento de Pessoal de Nível Superior (CAPES) and the Fundação de Amparo à Pesquisa do Estado de São Paulo (FAPESP) for PhD fellowships (grants \#2010/07809-1 and BEPE-Fapesp \#2012/13762-3). Authors extend the acknowledgment to FAPESP for the financial support (grants \#2007/59779-6 and FAPESP-VALE grant \#2010/51307-0). GH and LPCM acknowledge the Conselho Nacional de Desenvolvimento Científico e Tecnológico (CNPq) for research productivity fellowships. Authors thank Dr. Pax Blamey and Dr. Mundayatan Haridasan for critical reviews on early versions of this manuscript and to Katharine Carroll for the English review. We also thank the Phenology Laboratory at UNESP for the support and access to the cerrado long-term phenology database.

\section{RESUMO}

Aflora do cerrado é composta por espécies acumuladoras e não acumuladoras de alumínio (Al), coexistentes em solos ácidos, ricos em $\mathrm{Al}$ e com baixa fertilidade. Apesar da coexistência desses grupos funcionais, sua importância ecológica e suas estratégias biológicas são pouco conhecidas. Nós estudamos os padrões fenológicos de brotação foliar de ambos os grupos ao longo do ano, as concentrações foliares de N, P, K, Ca, $\mathrm{Mg}, \mathrm{S}, \mathrm{Al}$, flavonoides totais e polifenóis e a área foliar específica (AFE) em folhas jovens e maduras, dentro e entre os grupos. Para as espécies acumuladoras de $\mathrm{Al}$ as brotações foliares foram distribuídas ao longo do ano, com maior intensidade entre maio e setembro; para as espécies não acumuladoras de $\mathrm{Al}$ observamos um pico de brotação durante a transição das estações seca e chuvosa. No entanto, estes comportamentos não podem ser associados às estratégias ligadas ao acúmulo foliar de metabólitos secundários por estes grupos funcionais. As espécies acumuladoras de $\mathrm{Al}$ apresentaram menores concentrações de nutrientes foliares, enquanto que as não acumuladoras concentraram mais macronutrientes e produziram folhas com alta AFE desde a fase juvenil. 
Isso demonstra que o aumento de AFE é mais lento nas espécies acumuladoras de $\mathrm{Al}$, que devem atingir valores de AFE comparáveis ao resto da comunidade apenas na estação úmida, quando a captação de luz é importante para o crescimento de novos ramos.

Palavras-chave: alumínio, comunidade, herbivoria, nutrição mineral, fenologia, área foliar específica.

\section{REFERENCES}

Alberton B, Almeida J, Helm R, Torres RS, Menzel A AND MORELLATO LPC. 2014. Using phenological cameras to track the green up in a cerrado savanna and its on-the ground validation. Ecol Inf 19: 62-70.

ARAÚJO GM AND HARIDASAN M. 1997. Estrutura fitossociológica de duas matas mesófilas semidecíduas, em Uberlândia, Triângulo Mineiro. Naturalia 22: 115-129.

ARENS K. 1958. Considerações sobre as causas do xeromorfismo foliar. Boletim da FFCL-USP 15: 23-56.

Box GEP AND COX DR. 1964. An analysis of transformations. J Royal Stat Soc 26: 211-252.

BRUNNER I AND SPERISEN C. 2013. Aluminum exclusion and aluminum tolerance in woody plants. Front Plant Scien 4: 1-12.

CAmargo MGG, Cazeta E, Schaefer HM and Morellato LPC. 2013. Fruit color and constrast in seasonal habitats - a case study from a cerrado savannas. Oikos 122: 13351342.

Camargo MGG, Souza RM, Reys P And Morellato LPC. 2011. Effects of environmental conditions associated to the cardinal orientation on the reproductive phenology of the cerrado savanna tree Xylopia aromatica (Annonaceae). An Acad Bras Cienc 83: 1007-1019.

COLEY PD AND BARONE JA. 1996. Herbivory and plant defenses in tropical forests. Ann Rev Ecol Syst 27: $305-$ 335.

Cortés-Rojas DF, Chagas-Paula DA, Costa FB, Souza CRF AND OLIVEIRA WP. 2012. Bioactive compounds in Bidens pilosa L. populations: a key step in standardization of phytopharmaceutical preparations. Braz J Pharmac 23: $28-35$

DANTAS VL AND BATALHA MA. 2011. Vegetation structure: fine scale relationships with soil in a cerrado site. Flora 206: 341-346.

FERREIRA JÚNIOR LG, YASHIOKA H, HuETE AR AND SANO EE. 2003. Seasonal landscape and spectral vegetation index dynamics in the Brazilian Cerrado: an analysis within the Large-Scale Biosphere-Atmosphere experiment in Amazônia (LBA). Rem Sens Environ 87: 534-550.

Franco AC, Bustamante M, Caldas LS, Goldstein G, MEINZER FC, Kozovits AR, RUNDEL P AND CORADIN VTR. 2005. Leaf functional traits of Neotropical savanna trees in relation to seasonal water deficit. Trees 19: 326-335.
GonÇALVES-Alvim SJ, KoRndorf G ANd FERnANDES GW 2006. Sclerophylly in Qualea parviflora (Vochysiaceae): influence of herbivory, mineral nutrients, and water status. Plant Ecol 187: 153-162.

GONÇALVES-ALVIM SJ,LANA TC, RANIERI BD AND FERNANDES GW. 2011. Test of hypotheses about herbivory and chemical defences of Qualea parviflora (Vochysiaceae) in Brazilian Cerrado. Braz J Bot 34: 223-230.

HABERMANN G AND BRESSAN ACG. 2011. Root, shoot and leaf traits of the congeneric Styrax species may explain their distribution patterns in the cerrado sensu lato areas in Brazil. Funct Plant Biol 38: 209-218.

HARIDASAN M. 1982. Aluminium accumulation by some cerrado native species of central Brazil. Plant Soil 65: 265-273.

HARIDASAN M. 1987. Distribution and mineral nutrition of aluminium-accumulating species in different plant communities of the cerrado region of Central Brazil. In: San José JJ and Montes R (Eds), La capacidad bioproductiva de sabanas. Instituto Venezolano de Investigaciones Cientificas, Caracas, p. 309-348.

HARIDASAN M. 2008. Nutritional adaptations of native plants of the cerrado biome in acid soils. Braz J Plant Physiol 20: 183-195.

HARIDASANMAND ARAÚJO GM. 1988. Aluminium-accumulating species in two forest communities in the cerrado region of central Brazil. Forest Ecol Manag 24: 15-26.

HaridasAn M AND ARAúJo GM. 2005. Perfil nutricional de espécies lenhosas de duas florestas semidecíduas em Uberlândia, MG. Rev Bras Bot 28: 295-303.

HofFMANN WA, FranCo AC, MoreIRA MZ AND HARIDASAN M. 2005. Specific leaf area explains differences in leaf traits between congeneric savanna and forest trees. Funct Ecol 19: 932-940.

Horst WJ, WANG Y AND ETICHA D. 2010. The role of the root apoplast in aluminium-induced inhibition of root elongation and in aluminium resistance of plants: a review. Ann Bot 106: 185-197.

JANSEN S, BROADLEY MR, ROBBRECHT E AND SMETS E. 2002a Aluminum hyperaccumulation in angiosperms: a review of its phylogenetic significance. Bot Rev 68: 235-269.

Jansen S, Watanabe T, CARIS P, GeUten K, Lens F, Pyck N AND SMETS E. 2004. The distribution and phylogeny of aluminium accumulating plants in the Ericales. Plant Biol 6: 498-505.

JANSEN S, WATANABE T, DESSEIN S, SMETS E AND ROBBRECHT E. 2003. A comparative study of metal levels in leaves of some Al-accumulating Rubiaceae. Ann Bot 91: 657-663.

JANSEN S, WATANABE T AND SMets E. 2002b. Aluminium accumulation in leaves of 127 species in Melastomataceae with comments on the order Myrtales. Ann Bot 90: 53-64.

Kissmann C, Tozzi HH, Martins S AND HabermanN G. 2012. Germination performance of congeneric Styrax species from the Cerrado sensu lato areas and their distribution pattern in different physiognomies. Flora 207: 673-681. 
KopittKe PM, Blamey FPC and Menzies NW. 2008. Toxicities of soluble $\mathrm{Al}, \mathrm{Cu}$, and $\mathrm{La}$ include ruptures to rhizodermal and root cortical cells of cowpea. Plant Soil 303: 217-227.

KÖPPEN W. 1948. Climatología con un estudio de los climas de la Tierra. Mexico: Ed. Fondo de Cultura Económica-Pánuco.

KuRSAR TA AND COLEY PD. 2003. Convergence in defense syndromes of young leaves in tropical rainforests. Bioch Syst Ecol 31: 929-949.

Kursar tA, Coley PD, Corley DG, Gupta MB, Harrison LA, ORTEGA-BARría E AND Windsor DM. 1999. Ecologically guided bioprospecting in Panama. Pharmac Biol 37: 114-126.

Kushwaha CP, Tripathi SK and Singh KP. 2011. Tree specific traits affect flowering time in Indian drytropical forest. Plant Ecol 212: 985-998.

MANTOVANI W AND MARTINS FR. 1988. Variações fenológicas das espécies do cerrado da Reserva Biológica de Mogi Guaçu, Estado de São Paulo. Braz J Bot 11: 101-112.

MARQUIS RJ, DINIZ IR AND MORAIS HC. 2001. Patterns and correlates of interspecific variation in foliar insect herbivory and pathogen attack in Brazilian Cerrado. J Trop Ecol 17: 127-148.

MARQUIS RJ, MORAIS HC AND DINIZ IR. 2002. Interactions among cerrado plants and their herbivores: unique or typical? In: Oliveira PS and Marquis RJ (Eds), The cerrados of Brazil. Columbia University, New York, p. 306-328.

MEDEIROS RA AND HARIDASAN M. 1985. Seasonal variations in the foliar concentrations of nutrients in some aluminium accumulating and non-accumulating species of the cerrado region of central Brazil. Plant Soil 88: 433-436.

Morellato LPC, ALBERTI LF AND HUdSON IL. 2010. Applications of circular statistics in plant phenology: a case studies approach. In: Hudson IL and Keatley M (Eds), Phenological Research: Methods for Environmental and Climate Change Analysis, Netherlands: Springer, p. 357-371.

Morellato LPC, TAlora DC, TAKaHASI A, BENCKE CC, ROMERA EC AND ZIPPARRO VB. 2000. Phenology of Atlantic rain forest trees: a comparative study. Biotropica 32: 811-823.

NASCIMENTO MT. 1987. Notas preliminares sobre a herbivoria foliar em Vochysia divergens Phol. Cienc Cult 39: 588589.

NASCIMENTO MT AND HAY JD. 1990. Variações intraespecíficas dos nutrientes em folhas de Metrodorea pubescens (Rutaceae) em dois tipos de mata do distrito federal. Acta Bot Bras 4: 145-152.

NASCIMENTO MT, VILLELA DM AND LACERDA LD. 1990. Foliar growth, longevity and herbivory in two "cerrado" species near Cuiabá, MT, Brasil. Rev Bras Bot 13: 27-32.

PINHEIRO F, DINIZ IR, COELHO D AND BANDEIRA MPS. 2002. Seasonal pattern of insect abundance in the Brazilian cerrado. Aust Ecol 27: 132-136.

RATTER JA, BRIDGEWATER S AND RIBEIRo JF. 2003. Analysis of the floristic composition of the Brazilian cerrado vegetation III: comparison of the woody vegetation of 376 areas. Edinb J Bot 60: 57-109.
RÉBula CA, Haridasan M, Kitayama K and Morais HC. 2008. Toxic Effects of Leaves of an AluminumAccumulating Plant on Laboratory Colonies of Atta sexdens (Hymenoptera: Formicidae). Sociobiology 52: 13-24.

REICH PB, OLEKSYN J AND WRIGHT IJ. 2009. Leaf phosphorus influences the photosynthesis-nitrogen relation: a crossbiome analysis of 314 species. Oecologia 160: 207-212.

Reys P, CAMARgo MGG, TeIXeIra AP, Assis MA, GROMBONE-GUARATINI MT AND MORELLATO LPC. 2013. Estrutura e composição florística entre borda e interior de um cerrado sensu stricto e sua importância para propostas de recuperação. Hoennea 40: 437-452.

Rossatto DR, HOFFMANN WA AND Franco AC. 2009. Differences in growth patterns between co-occurring forest and savanna trees affect the forest-savanna boundary. Func Ecol 23: 689-698.

Rossatto DR, HoFFMANn WA, Silva LCR, Haridasan M, Sternberg LSL AND FranCo AC. 2013. Seasonal variation in leaf traits between congeneric savanna and forest trees in Central Brazil: implications for forest expansion into savanna. Trees 27: 1139-1150.

RYAN PR, TYERMAN SD, SASAKI T, FURUICHI T, YAMAMOTO Y,ZHANG WH AND DELHAIZE E. 2011. The identification of aluminium-resistance genes provide opportunities for enhancing crop production on acid soils. J Exp Bot 62: 9-20.

SARRUGE JR AND HAAG HP. 1974. Análises químicas em plantas. Piracicaba, ESALQ, 54 p.

Silva DM AND BATALHA MA. 2011. Defense syndromes against herbivory in a cerrado plant community. Plant Ecol 212: 181-193.

SILVA IA AND BATALHA MA. 2006. Taxonomic distinctness and diversity of a hyperseasonal savanna in central Brazil. Divers Distrib 12: 725-730.

TEKLAY T. 2004. Seasonal dynamics in the concentrations of macronutrients and organic constituents in green and senesced leaves of three agroforestry species in southern Ethiopia. Plant Soil 267: 297-307.

VARANDA EM, BAROSELA JR, OKI Y, PAIS MP AND CERRI A. 2005. Defesas vegetais contra insetos folívoros. In: Pivello $\mathrm{R}$ and Varanda EM (Eds), O Cerrado pé-de-gigante, ecologia \& conservação. São Paulo: Secretaria do Meio Ambiente, p. 195-208.

VARANDA EM, COSTA AA AND BAROSELA JR. 2008. Leaf development in Xylopia aromatica (Lam) Mart. (Annonaceae): Implications for palatability to Stenoma scitiorella Walker 1864 (Lepidoptera: Elachistidae). Braz J Biol 68: 831-836.

VON UEXKÜLL HR AND MUTERT E. 1995. Global extent, development and economic impact acid soils. Plant Soil 171: 1-15.

WOISKY RG AND SALATINO A. 1998. Analysis of propolis: some parameters and procedures for chemical quality control. J Apic Res 37: 99-105.

ZAR JH. 1999. Biostatistical Analysis. Prentice Hall, Englewood Cliffs, New Jersey. 
